\title{
Epistemic Struggles in the Legal Field- Speech Rights, Memory, and Genocide Curricula before an American Court
}

\author{
by Joachim J. Savelsberg and Brooke B. Chambers
}

Epistemic struggles unfold not only in the political field, but also in courts of law. Particularly in the United States, the legal field serves as a frequent battleground when questions of knowledge and denial are at stake. In line with the neoDurkheimian tradition discussed in chapter 6 , such battles take the form of rituals, suited to impress on the public a sense of shared norms and facts, right and wrong (Smith 2008).

Struggles between denialist intent and the desire to recognize genocide unfolded in several legal disputes. Prominent among them was Griswold v. Driscoll, a court case carried out in Massachusetts between 2005 and 2010. At stake were guidelines for teaching about the Armenian genocide issued by the Massachusetts Department of Education. The case pitted actors who self-defined as free speech advocates, but were considered denialists by their opponents, against the Department of Education. While several actors on the side of the State agreed that this was a case about free speech, many simultaneously expressed concern with memory and values, considering Griswold v. Driscoll a fight for recognition of the violence against the Ottoman Armenians as genocide. Examining this case, we discovered fascinating mechanisms. First, a subterranean engagement with substantive concerns took place under the cover of formal arguments. Second, a form of 
decoupling separated "front stage" actors organized around free speech rights from "back stage" actors concerned with denial of the genocide.

While this chapter builds on a long tradition of work on the cultural effects of prosecutions and criminal trials of perpetrators of mass violence (Marrus 2008; Pendas 2006; Hagan 2003; Savelsberg and King 2007, 2011; Savelsberg 2015; Savelsberg and Nyseth Brehm 2015), it goes beyond previous work in three ways. First, it shifts attention from trials of suspected perpetrators to court cases that explicitly address the generation and dissemination of knowledge about mass atrocity and genocide. Second, it highlights the strategic use of trials and their cultural potential by powerful actors who explicitly seek to affect knowledge about the past. Third, while taking the rules of the legal game and the institutional logic of formal law seriously, this chapter also investigates cultural effects of trials that result from informal aspects of legal proceedings, their initiation, their unfolding, and their use as platforms from which to talk to a broader public during and after the trial. Participants use the proceedings as a stage. Some of their arguments, even if not formally relevant, might yet affect court decisions; they certainly do reach various audiences inside and outside of the court.

\section{INSIGHTS FROM PAST SOCIO-LEGAL LITERATURE: RITUALS, LAW, AND KNOWLEDGE}

Scholarship has shed light on cultural effects of trials, the role of strategic and powerful actors in legal rituals, formal and substantive concerns in legal proceedings, and tensions between free speech claims and fights against denial. Insights from this literature can help us understand struggles over knowledge concerning the Armenian genocide. It is thus worth diving into this literature before examining a significant judicial fight over genocide versus free speech claims, carried out in a U.S. court, and pitting Turkish denialism against Armenian struggles for recognition: Griswold v. Driscoll.

\section{Rituals and Law in the Hands of Powerful and Strategic Actors}

Power and culture are mutually constitutive, generally and in the legal field. Trials produce culture - in this case knowledge about genocide-while simultaneously being shaped by interests and power. Consider the International Military Tribunal (IMT) at Nuremberg. Responding to the Nazi crimes by way of a trial was not a foregone conclusion. The victorious powers disagreed about appropriate responses. President Franklin D. Roosevelt eventually agreed to holding trials, "determined that the question of Hitler's guilt-and the guilt of his gangsters-must not be left open to future debate. The whole nauseating matter should be spread out on a permanent record under oath by witnesses and with all the written documents" 
(according to his confidant Judge Samuel Rosenman, cited in Landsman 2005:6; see also Douglas 2001). One of Roosevelt's goals was to undermine domestic support for American isolationism that had grown during the post-World War I era.

History-writing expectations, paired with anti-isolationist leanings, not only contributed to the initiation of the IMT. They also colored the structure of the trial. Words by Robert Jackson, American chief prosecutor at the IMT, indicate that much: "Unless we write the record of this movement with clarity and precision, we cannot blame the future if in days of peace it finds incredible the accusatory generalities uttered during the war. We must establish incredible events by credible evidence" (quoted in Landsman 2005:6-7; our emphasis). More specifically, charging a relatively small number of leading Nazis, the Allies allowed the majority of Germans to be ritually divorced from their past leaders. Cultural sociologist Bernhard Giesen (2004a) calls this a decoupling effect, through which many are (at least judicially) absolved while guilt is attached to a few. In addition, the organizers of the trial selected defendants carefully so that each would represent a major organization of the Nazi state. The expected guilty verdicts thus not only served as degradation ceremonies toward the defendants (Garfinkel 1956) but also delegitimized the organizations they represented, separating them ritually from the majority of the German people.

Such strategizing continued in the subsequent Nuremberg trials, held by the United States in the U.S.-occupied zone of Germany. Each trial was dedicated to a select number of individuals from different professional groups such as lawyers, physicians, and industrialists who had collaborated with the Nazi state. Again, a decoupling effect was to separate the majority of professionals from a small number of perpetrators as historian Michael Marrus (2008) critically documents for the Nuremberg "Doctors' trial."

Identifiable strategic actors in the realms of politics and law thus initiated the post-World War II trials and determined their structure. They sought to generate an image of the past in line with the law, but also in line with their geopolitical interests. These actors depended on power and authority, which the total defeat of the Nazi state and the military occupation of Germany provided.

Actor-driven intent, backed by power and authority, is certainly not unique to the IMT, as documented by political scientists, historians, and sociologists for many other court cases against perpetrators of mass atrocity. A prominent example is the trial of Adolf Eichmann, the organizer of the transportation of Jews to the extermination camps. The Israeli secret service captured and abducted Eichmann from Argentina, his place of refuge, and the Israeli government put him on trial in Jerusalem (Arendt 1963). David Ben-Gurion, Israel's prime minister at the time, was determined to reawaken Israelis' engagement with the Holocaust, especially among the younger generation. In Germany, Fritz Bauer, minister of justice of the state of Hesse, was the driving force toward the initiation of the Frankfurt Auschwitz trial of 1962-63 (Pendas 2006). To break the silence about the 
Holocaust that had ruled supreme during the first postwar decades, Bauer wanted a single trial for many defendants, and his efforts bore fruit. All of these initiatives aimed at (re-)awakening memory and shaping knowledge.

Interest-driven strategic actors also drove recent international judicial responses to mass atrocity. In the case of Yugoslavia, they include jurists and prosecutors (Hagan 2003), diplomats (Scheffer 2012), and social movement leaders (Neier 2012). Consider further the UN Security Council's 2005 referral of the situation in Darfur, Sudan, to the International Criminal Court (ICC) (Savelsberg 2015). Without the massive engagement of American civil society groups under the umbrella of the Save Darfur movement, the George W. Bush administration would likely have vetoed a referral of the case to the court to which it stood in opposition. Eventually, ICC intervention substantially colored the representation of the violence of Darfur in prominent news media across the Western world (Savelsberg and Nyseth Brehm 2015).

In short, a study of cultural consequences of human rights trials needs to consider social, political, and legal actors who initiate and structure court cases. We think of these legal actors as knowledge entrepreneurs with strategic interests and varying degrees of power. This is in line with Maurice Halbwachs's (1992) arguments regarding the presentism of collective memory, the notion that interests of today's actors shape memories of past events, even if in a path-dependent fashion (Olick 1999).

\section{From the Legal Field and Its Rules of the Game to Substantivized Law}

Once strategic actors decide to pursue the production of knowledge through legal trials, they avail themselves of a potentially powerful tool. Yet they also pay a price by tying themselves to the rules of the law (Thompson 1975). Pierre Bourdieu (1987), examining law as one specific social field within modern societies, highlights that, like actors in all other fields, legal actors seek to advance their own power and status. Yet ways to secure power and status are constrained by each field's particular rules of the game. Socialized into such constraints, actors develop a specific habitus, a set of relatively fixed dispositions that reflect their trajectories and their position within the field (Bourdieu 1987; see also Emirbayer and Johnson 2008). Rules of the legal field prescribe, for example, who can charge a crime, who can speak at a trial, what utterances the judge will allow, and which evidence the jury can consider when deciding on the guilt of defendants. In the adversarial system, the judge acts as an umpire, ensuring that trial participants follow these rules, disqualifying statements and actions that offend against them.

Playing by the rules of the game includes adhering to a specific logic that is inherent to the institutions within the field. In criminal law, for example, a final and binding decision has to be reached regarding the criminal liability of individual defendants. Social structures and larger cultural patterns that enabled a murderous event may interest sociologists, but they are irrelevant for the court. In 
addition, to secure due process, only some kinds of evidence are admissible in the court of law, different from those a social scientist would consider. Further, a trial's time horizon tends to be limited. Longer historical trajectories, of central interest to historians, are immaterial. Finally, the decision of a criminal court is binary, between guilty and not guilty, disregarding shades of gray that a social psychologist would take seriously. These elements of the institutional logic of criminal law become absorbed into the habitus of lawyers who operate in the context of criminal courts.

Recent scholarship has identified pronounced traces of such logic in the narratives generated through criminal trials. These traces are particularly evident when contrasted with competing narratives, generated in other social fields with different rules of the game (e.g., Savelsberg and King 2011, on the My Lai trial; Pendas 2006, on the Frankfurt Auschwitz trial; Marrus 2008, on the "Doctors' trial").

Yet, while formal law, with its rules of the game and its institutional logic, demands obedience from legal actors, and while it does color legal representations, a sole focus on formal rules misses important aspects of law in action.

First, participants in court proceedings may use the court as a stage to express their understanding of events, even if these accounts do not enter into the court's record or affect its decision. Second, what participants perform, whether it is formally admissible or not, potentially affects perceptions and actions of audiences outside the court. Third, legal decision makers operate with varying degrees of discretion that leave room for extralegal considerations. Discretion varies by type of law and historical time. Some eras celebrate formal features of law, while others open the gates to, in Weberian terms, substantivation of law, an increasing orientation of legal decision making toward extralegal criteria (Savelsberg 1992; Weber 1978; relatedly, see Unger 1976; Nonet and Selznick 1978; Stryker 1989). Such criteria may affect which facts of the case will be considered, and to what degree, in court decisions (e.g., offense versus social context), and they may concern the goals toward which law is oriented (e.g., retribution versus social peace).

The notion of substantivized law is consistent with Bourdieu's view of habitus, which, despite its focus on rules, also leaves room for improvisation. Bourdieu referred to jazz musicians or basketball players for an illustration, but we may extend the argument to lawyers. No matter the discipline, players would be disqualified if they did not follow the rules of their game, but they would be incapable of playing successfully were they not skilled improvisers.

Max Weber (1978) points at three driving forces that are likely to advance substantivation. First, legal clients to whom the notions of formal law are alien seek pragmatic solutions to their problems. Second, social activists seek interpretations of law that reach beyond formal rights to embrace social justice. Third, lawyers resist a law that reduces them, using Weber's terms, to automatons that, after one inserts the facts and the fees, spew out the decision and opinion. Lawyers' social status, after all, depends on the exercise of an appropriate level of discretion. In 
court cases involving grave human rights violations, each of these three factors weighs strongly against the pursuit of purely formal law. Audiences are especially alert when incidents of mass violence are at stake. Courts, responsive to their sensitivities, encourage public attention. The IMT, for example, removed the back wall of the courtroom to allow for a larger representation of the world's media. Contemporary human rights courts such as the ICC run substantial media departments and set up sophisticated websites.

Public attention intensifies further when movement organizations and NGOs are involved in the mobilization of legal action. Regarding the consideration of extralegal outcomes of trials, stakes tend to be especially high in cases of mass atrocity crimes, even more so when violence is ongoing, or when political or military leaders might easily reignite violence or recede from peace agreements (Savelsberg 2015). Similarly, when historic cases of mass atrocity are at stake and identities of entire national, ethnic, racial, or religious groups are tied to the acknowledgment of past victimization, courts are under substantial pressure to be mindful of their sensitivities. Human rights cases thus bring a variety of issues into the courtroom: emotions and values as well as cultural trauma and collective identities (Alexander et al. 2004). ${ }^{1}$

In short, we take formal law, Bourdieu's rules of the game, law's institutional logic, and the related legal habitus seriously, but we also recognize discretion, room for improvisation, and the consideration of extralegal criteria in court processes. Captured in the Weberian term substantivation of law (Savelsberg 1992), conceived of by others as technocratized law (Stryker 1989), responsive law (Nonet and Selznick 1978), or neoliberal law (Unger 1976), we expect these forces to have special weight in court cases that involve issues of human rights and historical responsibility as they clash with free speech claims.

\section{Free Speech Claims and Historical Responsibility in Court: \\ Toward the Armenian Case}

Moving beyond court cases against actors charged with mass atrocity crimes, scholars have now begun to examine lawsuits against those charged with misrepresenting past episodes of mass violence. Several factors account for the increase of such cases that typically pit free speech claims against demands for recognition of past violence. First, legal responses to human rights violations are historically new, and they have increased in the post-World War II era. Second, groups that have experienced victimization increasingly demand recognition. African Americans during and after the civil rights movement (and with renewed determination in 2020) and Jews in the post-Shoah era are but examples. Acknowledgment of their suffering reinforced the desire for recognition among those whose suffering had previously been silenced. In this climate, court battles began to erupt against actors who denied victimization and, in reverse, against others whose claims of genocide the alleged perpetrators deemed defamatory. 
The case against Princeton historian Bernard Lewis cited in chapter 7 is an early example, and more detail on that case will be helpful here. On May 19, 1985, an advertisement appeared in the New York Times and the Washington Post, sponsored by the Assembly of Turkish American Associations (ATAA). This ad cast doubt on the identification of the violence against Ottoman Armenians during World War I as genocide. Sixty-nine academics signed the ad, including Lewis, one of America's foremost authorities on the history of the Ottoman Empire. The action sought to discourage members of the U.S. House of Representatives from passing Resolution 192, which would have applied the term genocide to the mass killings of Armenians. Eight years later, in 1993, Lewis traveled to France on the occasion of the publication of two of his books in French. In an interview with journalists of the daily Le Monde, he praised the Turkish government, argued in favor of Turkey's admission to the European Union, and-when asked about the Armenian genocide-referred to it as "the Armenian version of the story." This interview provoked not only a rejoinder by thirty intellectuals and academics, but also civil law suits brought by the Forum of Armenian Associations of France and by a Committee for the Defense of the Armenian Cause. The latter group simultaneously initiated criminal proceedings, based on the Gayssot Act, passed by the French legislature in 1990, aimed at Holocaust denial but framed more broadly. The trial was held on October 14, 1994. Lewis offered a partial correction of his position, but he insisted on the absence of explicit orders by Ottoman leaders to exterminate Armenian life, a precondition for the application of the term genocide according to the Genocide Convention. The court eventually found Lewis guilty and sentenced him to a symbolic monetary penalty of one franc (Ternon 1999) and to compensating the charging groups for their legal expenses, amounting to 14,000 francs.

Almost two decades later, another European case attracted attention. Doğu Perinçek, a Turkish politician and lawyer, chair of the left-wing nationalist Patriotic Party, had publicly declared-during a visit to Switzerland-that the killing and deportation of Armenians in the context of World War I was a necessary consequence of the war and did not constitute genocide. The Swiss authorities prosecuted Perinçek, and the court convicted him of racial discrimination in March 2007. The judges relied on the official Swiss recognition of the Armenian genocide and on article 261, paragraph 4 of the criminal code that penalizes denial and justification of genocide. After a Swiss appeals court confirmed the decision, Perinçek filed an appeal to the European Court of Human Rights (ECHR). In a five-to-two vote, the ECHR overruled the Swiss decision. It argued that Perinçek's statements did not entail a call for violence, that free speech is legitimate in the search for historical truth, that the qualification of anti-Armenian violence by the Ottoman Empire is still debated, and that it is not up to judges to decide whether the claimant's statements threaten the identity of a people (for details, see Langer 2014). The court also referred to Spanish and French court cases with similar outcomes. 
Generally, the position of European courts seems to have shifted, during the 1990 s and 20oos, toward a more robust protection of free speech rights, known from U.S. law, and against the legal enforcement of recognition claims by victimized groups.

In light of such developments abroad, how did U.S. courts decide in free speech cases that pertain to the Armenian genocide? Material to answer the question abounds, because claimants-typically involving Turkish lobbying groupscontested the use of the term genocide on several occasions. In 2010, for example, the Turkish Coalition of America (TCA) sued the University of Minnesota and its Center for Holocaust and Genocide Studies (CHGS). On its website, the CHGS included the following disclaimer alongside TCA and other Turkish sources: "Warnings should be given to students writing papers that they should not use these sites because of denial, support by an unknown organization, or contents that are a strange mix of fact and opinion" (Turkish Coalition of America, Inc. v. Bruininks, o:10-cv-04760-DWF-FLN [MN District] [2010], Mar. 30, Memorandum and Order:3). The complaint claimed that CHGS engaged in censorship. Though the CHGS later removed the list of unreliable sources and replaced it with a general disclaimer about vigilance in evaluating source credibility, the TCA lost the lawsuit on its censorship claims.

Another instance of litigating discussion of the Armenian genocide unfolded in California in Movsesian v. Victoria Versicherung AG. In this case, the legal conflict was initially over insurance claims. In 2000, California passed a law that extended the statute of limitations for insurance claims made by survivors of the Armenian genocide who had lacked the resources to comply with the time limits. The insurance companies claimed that the California law was unconstitutional because the State had used the genocide label, thus interfering with the federal government's foreign policy authority. Remember that the U.S. federal government had not recognized the Armenian genocide. The Ninth Circuit Court of Appeals overturned the initial district court decision that had upheld the extension, ruling that the California law overstepped state authority and violated the foreign affairs doctrine (Movsesian v. Victoria Versicherung AG, 07-56722 [U.S. Court of Appeals, 9th Circuit]).

Lawsuits initiated by Turkish or Turkish American organizations, often in alliance with lawyers specializing in free speech cases, do not unfold in a vacuum. Turkish engagement against genocide claims had intensified in the 1970s, partially in response to the first modern historical studies by Armenian American scholars such as Richard Hovannisian (2002) and V.N. Dadrian (2002) and the consideration by Congress of recognizing the Armenian genocide (Zarifian 2014, 2018). In 1975, Turkey hired the public relations firm Manning Selvage \& Lee, and later it hired additional firms, including Hill \& Knowlton (which had earlier served the tobacco industry against claims that smoking constituted a health risk) (Mamigonian 2015). Mustafa Şükrü Elekdağ, Turkey’s new ambassador to Washington, played a major role. Furthermore, 1982 witnessed the foundation of an Institute for Turkish Studies at Georgetown University, established with a 
grant by the Turkish government and directed by Ottoman scholar Heath Lowry. Additional funding came from the defense industry, with an interest in weapons exports to Turkey. In 1985, Lowry crafted statements for advertisements in the New York Times and the Washington Post, cited above, that challenged the genocide claim. Lowry also wrote critical reviews on scholarship that acknowledged the Armenian genocide and sent them to the Turkish ambassador in Washington, who almost literally used these reviews in letters to prominent scholars, encouraging them to adopt his (or Lowry's) critical arguments for future publications (Smith, Markussen, and Lifton 1999). In 2009, the TCA funded the establishment of a Turkish Studies Project under the leadership of Hakan Yavuz at the University of Utah. The project was to become the source for numerous denialist claims and attacks on genocide scholars such as Hans-Lukas Kieser. Developments culminated in the 2008 claim by ATAA president Ergün Kirlikovali that "The Turks are the new Jews. Genocide crowds are the new KKK" (quoted in Mamigonian 2015:76). Plaintiffs in Griswold v. Driscoll (and similar cases) cited publications of these institutions as authoritative sources of knowledge from which they drew in forming legal arguments.

In short, in a politically and affectively charged atmosphere, strategic actors seek to mobilize law in battles over recognition of mass violence as genocide, here in regard to the Ottoman Armenians. In epistemic struggles, actors use formal arguments, drawing on free speech rights and substantive claims involving historical truth and issues of dignity and identity.

\section{A COURT CASE AND ITS CONTEXT: GRISWOLD V. DRISCOLL}

The Griswold v. Driscoll case, regarding guidelines issued by the Massachusetts Department of Education for teaching about the Armenian genocide, lends itself to a sociological exploration of epistemic struggles over genocide recognition in legal contexts and their mobilizing force. Massachusetts is home to one of the largest Armenian American communities in the United States. Watertown, a suburb of Boston, is the site of both the Armenian Museum of America and the Armenian Weekly, a publication focused on issues of interest to Armenian Americans. Neighboring Belmont is the seat of the National Association for Armenian Studies and Research. It is thus not surprising that Massachusetts has a long history of supporting Armenian Americans, for example through regular April 24 gubernatorial proclamations and legislative resolutions, beginning in 1965, that recognize the Armenian genocide.

Below, we introduce the main actors and basic features of the case, describe our data, and subsequently juxtapose a formal account of the legal proceedings with a substantivized, value-driven alternative understanding of the case's initiation, unfolding, and audience reception. 


\section{Basics of the Case}

In August 1998, the Massachusetts General Court approved chapter 276 of the annual Acts and Resolves, legislating that the Massachusetts Board of Education create a document to provide curricular guidelines on the teaching of genocide and human rights in the state's schools. The court called for the board to include discussion of the slave trade, the Holocaust, and the Armenian genocide, among other cases it might see fit to include in the document. On January 15, 1999, the board released an initial draft of this curriculum guide for public feedback. "The Massachusetts Guide to Choosing and Using Curricular Materials on Genocide and Human Rights Issues" provided brief summaries of historical human rights abuses accompanied by lists of suggested sources for teachers to utilize in their classrooms. Within the initial review process, individuals or groups were invited to provide the Board of Education with suggested changes or additional sources.

Over the subsequent years, the content of this guide was contested in federal court in the Griswold v. Driscoll case, at both the district and appellate levels. The court case unfolded in four steps. On October 26, 2005, a group of students, parents, teachers, and the ATAA filed a lawsuit against the Department of Education and other actors before the U.S. District Court, District of Massachusetts. On June 19, 2009, the court ruled against the claimants. On August 11, 2010, the First Circuit Court of Appeals upheld the ruling. Finally, on January 19, 2011, the U.S. Supreme Court declined to hear an appeal.

The plaintiffs, made up of local students and teachers, as well as a Turkish American community organization, sued the Massachusetts Board of Education in regard to "contra-genocide" content they had asked the board to include in the guide. This content challenged the application of the genocide label to the mass violence directed against Ottoman Armenians in the context of World War I. The debate over the guide's content dealt with themes of genocide denial and memory, free speech and censorship, and the intersections of politics, ethics, and law. These contestations provided the stage for both formal legal debate and negotiations of memory in the courtroom and beyond.

\section{Uncovering the Logic of a Trial through Court Documents and Interviews}

Our analysis of the case is based on two data sources: court documents and interviews. Using two legal databases, Bloomberg Law and Westlaw, we were able to access over a thousand pages of court documents from both the district and appellate cases. After accessing these remotely, a visit to the Massachusetts courthouse and use of onsite court records confirmed that we have access to the complete docket for each case. We reviewed these documents to chart general arguments from the plaintiffs, defense, amicus brief authors, and judges. We then coded interviews and key documents for themes about denial and free speech, as well as extrajudicial content. 
In addition to the analysis of court documents, we conducted in-depth interviews with several actors involved in the case. We interviewed members of the defense and plaintiffs, including lawyers, activists, a teacher, and a student. In general, plaintiffs expressed more hesitancy to participate in this study. Several declined to be interviewed. In addition, we spoke with reporters and with members of the current Department of Education to better understand both the perception and the lasting curricular effects of the case. The latter interviews also provide insights into the procedures of guideline promulgation.

Interviews complicate the neat picture painted by the court documents, as we will see. While the documents show finalized arguments, the interviews provide clearer insight into the social processes that enabled their creation, the motivation of actors, and the meaning individuals attributed to their actions. We asked participants about their initial motivations to join the case, including discussion of their previous knowledge about the Armenian genocide and early debates (both legal and extralegal) surrounding the case. We then inquired into their participation throughout the case, including their individual roles, their perceptions of the case, and their interactions and conversations with others as Griswold v. Driscoll unfolded. We concluded with an inquiry into lasting effects of the case on personal, legal, and communal dimensions.

Combining insights from the analysis of court documents and interviews provides us with insights into both the formal legal process and the cultural trauma, identity, and values mobilized throughout the unfolding case. It allows us to chart the arguments as they were constructed within and outside of the courtroom, while also accounting for the numerous legal, political, and moral incentives that shaped these proceedings and influenced their effects.

\section{From Administrative Process and Pre-legal Controversies to the Court Case}

The Massachusetts Board of Education first circulated a draft of the curriculum guide on January 15, 1999. As part of the review process, the board requested public feedback. Days after the draft was released, the Turkish American Cultural Society of New England (TACS-NE), affiliated with the national ATAA, contacted the Board of Education with a request that additional materials be included. As it stood, the guide's suggested resources all supported the categorization of the violence against the Armenians as genocide. The Turkish organizations instead asked that sources be included that called this labeling into question. The TACSNE argued that reputable scholars contested the assertion that the Turkish state had advocated a formal genocidal policy, and therefore that the mass killings of Armenians did not meet the legal definition of genocide. The board then incorporated these "contra-genocide" materials in the guide before circulating a second draft for review in March 1999. When local Armenian American organizations got word of this update, they contacted the board to request that the added 
"denialist" materials be removed from the guide, claiming that these documents negated the historical fact of the Armenian genocide. They argued further that, beyond being inaccurate, these materials caused pain to survivors and the descendants of survivors and victims. The board subsequently removed the Turkish sources in the final version of the curriculum guide, a move that motivated the initiation of the Griswold v. Driscoll case.

\section{Griswold v. Driscoll: Initiating the Case}

A series of questions arise about the initiation of the case: Who activated the law in this dispute? Who initiated the court case, based on which law? In line with the distinction between formal versus substantivized law, explored above, different answers come to the fore.

A formal perspective. The formal perspective is well reflected in the name of the case-Griswold v. Driscoll, referring to two individual actors: Theodore (Ted) Griswold, a Massachusetts high school student, and David Driscoll, the Commissioner of Education. It seems as though Ted (rather than David) rose against Goliath. Yet names of court cases leave out essentials. The "Complaint and Jury Demand" the plaintiffs filed with the U.S. District Court, District of Massachusetts, on October 26, 2005, lists, on the side of the plaintiffs, Theodore Griswold "and his parent and next friend, Thomas Griswold,"2 as well as William Schechter (Griswold's social studies teacher), Lawrence Aaronson, another social studies teacher at the same school, and the ATAA. Two additional students and their fathers later joined these plaintiffs. Ted Griswold was represented by attorney Harvey Silverglate, known for his pursuit of free speech cases, especially in educational settings. On the side of the defendants, we find listed "David P. Driscoll, Commissioner of Education, Massachusetts Department of Education, in his official capacity, James A. Peyser, Chairman, Massachusetts Board of Education, in his official capacity, The Department of Education for the Commonwealth of Massachusetts, and the Massachusetts Board of Education." Other defendants later joined the case, including intervenor defendants from the local Armenian American community.

The students and teachers claimed that the removal of materials suggested by Turkish organizations had violated their free speech rights and that the State had censored students' and teachers' access to educational material. The ATAA joined the plaintiffs - they openly did so as the producer of some of the removed sources-but also claimed to represent Turkish parents and students who were, in their view, facing discrimination. The plaintiffs expressed their belief "that the truth of an idea cannot be tested in a marketplace artificially circumscribed by censorship and the imposition of government orthodoxies." They summarized their goal as "a judicial declaration that actions taken by the Massachusetts Department of Education and by the Massachusetts Board of Education to excise 
academically sound materials from a state human rights curricular guide because of political hostility toward certain viewpoints have violated their rights to free expression and belief guaranteed by the United States Constitution" (Griswold v. Driscoll, 1:05-cv-12147-MLW [MA District Court] [2009], Nov. 25, Complaint and Jury Demand: 2).

The remainder of the "Complaint and Jury Demand" takes all the legally required steps. It clarifies the jurisdiction of the court, introduces the parties, and presents the facts of the case, as seen by the plaintiffs. A core passage states: "The [guideline] summary argued that the 'Muslim Turkish Ottoman Empire' was responsible for the deaths of large portions of the Armenian population of the Ottoman Empire around the time of World War I. No resources that mentioned the contra-genocide perspective on this period in history were included in the draft Guide, even though the Guide stated that one of its standards for selecting instructional materials on genocide and human rights issues was to provide 'differing points of view on controversial issues" (Griswold v. Driscoll, 1:05-cv12147-MLW [MA District Court] [2009], Nov. 25, Complaint and Jury Demand:8). The document concludes with the legal norms the plaintiffs consider to have been violated, notably the Federal Civil Rights Act, 42 U.S.C., paragraph 1983, and the First and Fourteenth Amendments of the U.S. Constitution.

In the same document, the plaintiffs also cite precedent to back up their constitutional claims. They refer to a 1982 case, Board of Education v. Pico, in which a local board of education in the state of New York removed several books from a school library, asserting that the removed books were morally unfit. Students in the district then sued, arguing that the board was employing noneducational motivations to censor student access to materials. After the district court ruled in favor of the board of education, the case rose to the U.S. Supreme Court, which affirmed the district court's decision but emphasized the centrality of the board's motivation in their interpretation of the law; the board could remove materials only for educationally legitimate reasons (Griswold v. Driscoll, 1:05-cv-12147-MLW [MA District Court] [2009], Nov. 25, Complaint and Jury Demand).

In Griswold v. Driscoll, the plaintiffs argued that the Massachusetts Board of Education removed documents from the teaching guidelines, interpreted as a virtual library, for political, rather than educational, reasons. Central to this argument, they claimed, is the educational legitimacy of the "contra-genocide" stance. Their arguments proclaimed the existence of a rigorous, two-sided debate about the appropriate labeling of the violence against Ottoman Armenians in 1915-16. The plaintiffs insisted that the State, in preventing such a debate by removing the "contra-genocide" content, had introduced into its educational guidelines political will. The plaintiffs asserted that this intrusion of politics into the educational sphere could disrupt the education of students as they learn to evaluate and analyze arguments, a position that the American Civil Liberties Union (ACLU) later supported in an amicus brief. 
A substantive perspective: actors behind actors, process behind process. While the court files capture the inclusion and removal of the documents and the legal arguments regarding violation, they do not convey the steps that led the plaintiffs to formally initiate the case, and this initiation remains contentious. Though the plaintiffs were outwardly united, they remained isolated behind the scenes. The teachers and students rarely, if ever, interacted with the Turkish lobbying group. All interviews indicate that the lead attorney, Harvey Silverglate, orchestrated the case without facilitating interactions between these groups. Consider the account provided by a former student who played a leading role in the case:

I became interested in the American Civil Liberties Union when I was in ninth grade in high school. And I think in tenth grade I approached Bill Schechter. . . He was a history teacher, and he was my journalism teacher at the time. And I threw the idea across his desk, and he was really into it. And we started the club together. It continued through the next three years that I was there, and I think it still existed for a few years afterwards ... ACLU Club. Like an extracurricular, after school we'd meet-we got involved in a few [issues], we were protesting the Patriot Act, you know, we'd just latch on to, like, certain causes. Gay marriage was a thing at the time in Massachusetts, and we got on board with that, and then Schechter, I think, was approached by Harvey, or he was friends with Harvey or something like that, and he was already a plaintiff as a teacher in the case, and explained to me the whole situation, that they needed a student ... and I was into the idea, and got involved.

The interview with this student reveals other sources of support, such as peers in the ACLU Club, a recent publication by "a Princeton professor" who had challenged the genocide label for the Armenian case, and a front-page article in the Wall Street Journal. As a high school student interested in civil liberties, the student experienced the article as a major thrill; while presenting both sides, it cited him and displayed sympathy for his cause. The driving force, however, according to the student, was attorney Harvey Silverglate, in whose house "four meetings" took place, over dinner, designed to tighten bonds and to strategize. The attorney's role was so central that the student never set foot in the courtroom. Our interview with a social studies teacher who played a central role in the case sheds additional light on the network ties within the group of plaintiffs. Attorney Silverglate approached this teacher through a colleague on the staff of the school. The teacher describes Silverglate as a member of Cambridge progressive circles, mentioning Silverglate's wife and her old friendship with Beat poet Allen Ginsberg.

Also in our interview, the student discussed challenges, including overwhelmingly negative press reactions, the upset of fellow students of Armenian descent, including a friend from the ACLU Club, and-especially-a call from an elderly Armenian woman:

I remember at one point, people were calling the school. I worked on the school newspaper at the time, and I was working after school. And for some reason the receptionist sent the call to me in that room—and it was a woman who was crying, 
because she said her parents had been beheaded in front of her in Armenia back in the day. And I had to talk to her, try to explain what we were doing. And I was just like-I can't do this, I can't really explain.... She was just going on and on about how this really happened. That's what she wanted me to hear and acknowledge. And so I was like, I do believe that, believe you, and that's terrible. And I'm sorry-you know, I'm not trying to deny that, or detract from that at all. But I started to try to defend the case the way we did typically. But then I was just like, for this woman, you can't really make some kind of abstract legal argument. So I was just like, I'm really sorry, I don't know very much about this. I'm involved with this case because I think it's important for this reason.

Despite such challenges, and his expressed empathy with a representative of the victim group, the student's excitement about being involved in a big civil liberties case prevailed. The student also confirmed that he continues to feel pride about his role in a case over free speech rights, and that he continues to admire Silverglate: "I still think it's cool that there are people like Harvey who really do know how those things work, and who see an important case-'cause they're always thinking about precedent, that's the whole point, it's not just about this case at all. It's really not, obviously. And-so he saw this as an important thing. ... And he was doing this work for free." 3 Yet the student also distanced himself from the case, culminating in the statement that he, who never set foot in the court and eventually lost sight of the case as it unfolded over several years, was not upset about the outcome: "And so-ultimately, if we lost, I'm just like, okay ... yeah, they won. Maybe the people who were upset about it, maybe it makes them feel a little better. I'm alright with that. ... I don't feel terrible-the Turks probably feel bad about it. But again, that's not why I was involved."

Obviously, the tie between the student and his admired teacher was crucial for their engagement in the case. Like the student, the teacher we spoke with also stressed that his sole interest was in free speech issues, not in a statement about the Armenian genocide. He expressed concern about the political determination of suggested instructional materials, especially in the context of high-stakes standardized testing. He also strongly articulated his belief in the pedagogical value of students being exposed to different sides of a debate, even if one side's arguments might appear outrageous, and for students to have to struggle with disparate positions. While he expressed sympathy with the Turkish position and referred to arguments by historian Bernard Lewis in this context, he stressed that the court proceeding had, in his perception, nothing to do with a statement about history. "Yes, the amicus people came up afterwards and gave their spiel, and it kind of - it had nothing to do with anything, except their deeply felt ideas, and support for the Armenian American community."

The interviews thus provide a sense of some of the plaintiffs, their network ties, and their substantive positions. Some actors were centered on the school setting, but linked with civil libertarian and free speech lawyer Silverglate and 
progressive-libertarian circles in Cambridge of which Silverglate was a part, and with which some social studies teachers were marginally linked. These plaintiffs were ambivalent regarding the historical question of the Armenian genocide; their focus was on free speech issues. Acting on the trial's "front stage", their network was organized around civil libertarian issues in the school setting.

Yet these plaintiffs did not act alone. They were joined by the ATAA as a co-plaintiff. The network ties between these two sets of plaintiffs are murky. Evidence suggests that the teachers and students did not have ties with the ATAA; multiple interviewees reported that they never interacted with ATAA representatives. The relationship between free speech lawyers and Turkish organizations, however, is more difficult to ascertain. Who was the driving force in this constellation, free speech lawyers or Turkish American organizations? Harvey Silverglate declined to be interviewed. Other participants suggested that the ATAA sought involvement because of the concerns of local Turkish Americans who feared that their children would receive prejudicial treatment in schools, based on the curriculum guidelines. Court documents do reveal that the Turkish American Legal Defense Fund (TALDF) hired at least one attorney as a consultant who had previously been involved in the University of Minnesota case cited above. That attorney later also wrote an amicus curiae brief for the TALDF.

In sum, while not all social ties and motives that lead to the initiation of a case such as Griswold v. Driscoll can be identified, our interviews render some of them visible. The pattern that emerges speaks to the difference between what appears through the formal setup of the case and the substantive reality of what drives it. On the one hand, we have progressive, civil libertarian high school teachers and their students. They act on the front stage, as it were. On the other hand, we find a network of free speech lawyers and Turkish and Turkish American organizations who are involved in multiple cases of this nature, but who remain backstage, at least in Griswold v. Driscoll. We were not able to ascertain who among the latter dominates in this dyadic relationship. Yet it seems clear that together they are the driving force that seeks out suitable actors, such as civil libertarian-oriented students and their teachers, to initiate cases and to serve as the "poster children" in what is meant to appear as a struggle over civil liberties.

We can depict the social structure of this group of actors in a Simmelian model of overlapping social circles (see figure 12). The first circle consists of civil libertiesengaged high school students, supported by parents and teachers. The second circle, partially overlapping with the first, consists of progressive-libertarian free speech attorneys. Among them, too, civil liberties concerns appear to dominate. The third circle, overlapping with that of the free speech lawyers, consists of Turkish or Turkish American organizations. Some plaintiffs argue that Turkish organizations joined the case at the pleading of local Turkish Americans who expressed concern over discrimination or animosity due to the curriculum guide. Yet, given the massive infringements on civil liberties in Turkey, the imprisonment of 


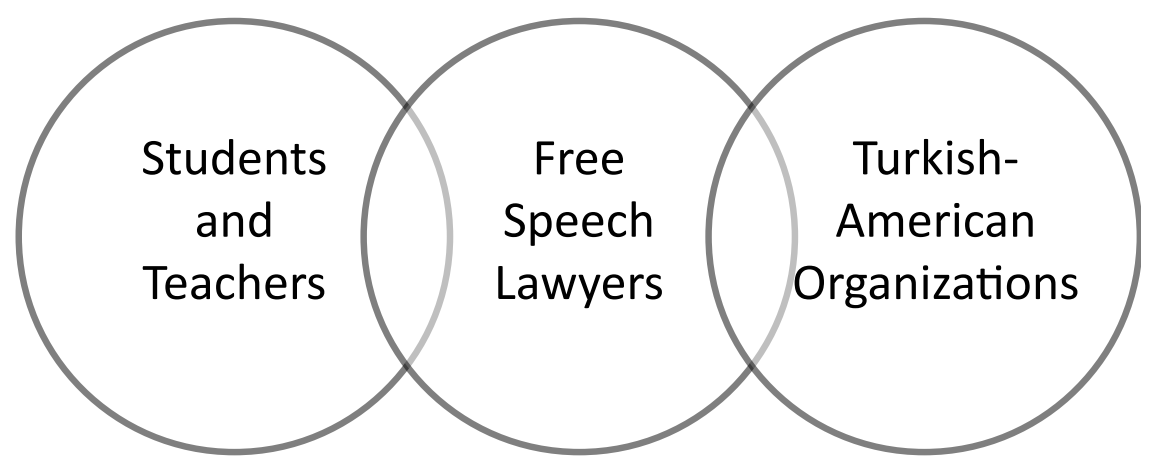

FIGURE 12. Social organization of plaintiffs and their discourses in Griswold v. Driscoll.

journalists and academics, and the criminalization of the mere use of the term genocide in regard to the mass killings of Armenians-and given, finally, these groups' silence vis-à-vis the repression of free speech in Turkey-it is implausible that free speech concerns in fact drove their actions. Instead, their intervention can only be understood as a new front in the struggle against recognition of the Armenian genocide. Through these interlinked social circles, substantive, extralegal concerns and their discursive expression hid behind formal free speech claims to motivate the initiation of the Griswold v. Driscoll case, even if that initiation was formally based on concerns with legal principles of the U.S. Constitution alone. A decoupling arrangement separated the front stage actors organized around free speech rights from the back stage actors concerned with denial of the genocide.

The initiation of the case by the plaintiffs and their supporters brought many other actors into the legal game. The defendants challenged the plaintiffs' position, various groups supported them through amicus briefs, and the judges deliberated and decided. The defendants and their supporters brought arguments into the unfolding trial that appealed to the issue of free speech or First Amendment protections. Yet they also raised issues that the plaintiffs had not formally addressed, but that appear to have motivated their action, at least partially. Central among them was the debate over the appropriateness of the genocide label for the mass violence against the Ottoman Armenians. Formally about free speech rights, the court case also involved a substantive debate about the Armenian genocide. Formal and substantive discourses in fact interpenetrate, as the following shows.

\section{Deliberation in Griswold v. Driscoll}

Over the course of six years, Griswold v. Driscoll unfolded in three courts. The majority of the legal disputes, however, took place outside of the courtroom. Plaintiffs, defendants, and contributors of amicus briefs submitted hundreds of pages of documents to the district and appellate courts, while only two formal hearings were held. 
A formal perspective: trial as procedure and the free speech issue. In September 2006, the U.S. District Court first heard the case. After nearly three years, Judge Mark Wolf ruled in favor of the defense. Speaking to formal matters of the case, he cited the legitimacy of political participation in the process of developing the instructional guide. He also rejected the plaintiffs' claims that censorship had occurred, denying Board of Education v. Pico as a precedent. In summarizing his opinion, the judge wrote the following:

The Complaint and attached exhibits demonstrate that plaintiffs and those who share their viewpoint concerning the treatment of Armenians in the Ottoman Empire are capable of participating fully in the political process, which provides the opportunity to petition the government to alter its policies. The efforts of the ATAA and the others who share its viewpoint evidently caused the inclusion of contra-genocide materials in the Curriculum Guide for a while. If plaintiffs still want those materials included in the Curriculum Guide, they will have to resume their efforts to prevail in the political arena because they are not entitled to relief in federal court. (Griswold v. Driscoll, 1:05-cv-12147-MLW [MA District Court] [2009], Jun. 10, Judgment: 30)

The judge did not explicate an opinion on the substantive dispute over the appropriate labeling of the mass violence against the Ottoman Armenians that had motivated major factions among both the plaintiffs and the defendants. We will never know what his position on this matter was or whether that position affected the court's decision.

In a next step, the plaintiffs appealed the district court's decision, taking the case to the appellate court. After a hearing and deliberation, Associate Justice David Souter (retired U.S. Supreme Court justice) confirmed the ruling of the district court. He affirmed that the Massachusetts Board of Education had not violated the First Amendment. Like Judge Wolf, he also denied the plaintiffs' censorship argument: "The revisions to the Guide after its submission to legislative officials, even if made in response to political pressure, did not implicate the First Amendment. The judgment of the district court is affirmed" (Griswold v. Driscoll, 09-2002 [MA Court of Appeals] [2010], Aug. 11, Judgment: 15). Again, the reasoning that carries the decision does not engage with the substantive debate over the appropriate labeling of the violence, and again we will never know whether such consideration affected the decision in any way.

Following this defeat, the plaintiffs sought to bring Griswold v. Driscoll before the U.S. Supreme Court, which, however, declined to hear the case. Following its notification of this decision on January 19, 2011, the case formally concluded.

In sum, while substantive debates over the genocide label, and associated identity issues, motivated much of the dispute, most clearly among Turkish American and Armenian American organizations, the courts never addressed those concerns. They instead stuck strictly, and in line with a formal legal logic, to constitutional arguments about free speech. 
TABLE 6 Formal-Legal and Substantive Arguments in Griswold v. Driscoll

\begin{tabular}{lll}
\hline & Defendants & Plaintiffs \\
\hline $\begin{array}{l}\text { Free Speech- } \\
\text { Formal }\end{array}$ & $\begin{array}{l}\text { (1) State has authority to regulate } \\
\text { educational curriculum }\end{array}$ & $\begin{array}{l}\text { (2) State overstepped by censoring } \\
\text { educational curriculum }\end{array}$ \\
Substantive & $\begin{array}{l}\text { (3) Violence against the } \\
\text { Armenians constituted genocide, } \\
\text { and Turkish lobbying groups }\end{array}$ & $\begin{array}{l}\text { (4) Violence against the Armenians } \\
\text { sides of the historical debate deserve }\end{array}$ \\
& $\begin{array}{l}\text { sought to include propaganda } \\
\text { in the state's educational } \\
\text { curriculum }\end{array}$ & to be heard \\
\hline
\end{tabular}

From a formal to a substantive perspective: court as stage-history, values, and identities. The previous section showed how both parties in Griswold v. Driscoll, while agreeing on what had occurred in the process of educational guideline promulgation, profoundly disagreed on the legality of the Massachusetts Board of Education's actions. The plaintiffs argued that the State had overstepped its authority by censoring the educational curriculum and that, by doing so, it had infringed on free speech rights of students and teachers. The defendants argued instead that the State had the authority to regulate the educational curriculum and that the omission of certain arguments did not constitute an infringement of free speech rights (this legal disagreement is represented in table 6, quadrants 1 and 2).

Yet the formal debate over free speech simultaneously allowed for two substantive arguments to unfold. On one side, a subgroup of plaintiffs, specifically Turkish American associations, argued that debates over the appropriate labeling of the mass violence against the Armenians are unsettled and that both sides of the historical debate are legitimate and need to be included in the curriculum (table 6, quadrant 4). On the other side, the defendants and writers of several amicus curiae briefs unanimously argued that violence against the Armenians constituted genocide, and that Turkish lobbying groups sought to introduce propaganda into the state's educational curriculum (table 6 , quadrant 3 ).

The contending positions manifested themselves in divergent terminologies. Where plaintiffs referred to "wartime conflict materials" or "contra-genocide materials," defendants used the term "denialist materials." Moreover, according to some participants, the mere presence of such contestations within the courtroom gave legitimacy to the contra-genocide perspective. As one Armenian American advocate put it: "To make it into the other side in a debate, you can agree or you can disagree, but if you're talking about it in its terms of being a debate, you're at least recognizing that there are two sides. And that's more than half the battle, in this case."

At times, this juxtaposition, and the simultaneity of formal free speech and substantive genocide arguments, resulted in actors talking past each other. It also resulted in uneasy alliances, managed by way of the interactional distance shown above in the example of civil liberties advocates on the one hand and Turkish American actors on the other, the latter allied with a country that criminalizes 
slanderous speech about the nation, including the use of the word genocide for the violence against the Armenians during World War I.

A very different pattern of relationships emerges on the side of the defense. Armenian American groups, other contributors of amicus briefs, and the State articulated similar arguments, all advocating the appropriateness of the genocide label. State actors differed somewhat, however, in that they prioritized the argument of legitimate governmental power and free speech rights. Accordingly, we observe intense interactions (largely overlapping social and argumentative circles) between Armenian American groups and the Massachusetts Department of Education, much in contrast to the decoupling we identified above on the side of the plaintiffs.

In short, while Griswold v. Driscoll was formally about free speech issues, the case also provided a space for a substantive debate about the Armenian genocide. The latter, in fact, was the central motivating force for many participants.

Interpenetration of formal and substantive debates. Importantly, participants in the legal fight did not just add substantive arguments to formal ones. Instead, the formal and the substantive interpenetrated in Griswold v. Driscoll. The topic of free speech specifically provided opportunities for both defendants and plaintiffs to insert substantive debates about the Armenian genocide into formal legal contestations. This insertion is most explicit in arguments over "educational legitimacy," or the existence of scholarly (versus political) support for documents suggested for the curriculum guide. Here substantive concerns were debated in formal rules-of-the-game terms, facilitating debates about the Armenian genocide under the cover of formal legal language. This mechanism enabled actors to interpret the Armenian genocide either as centrally important or as irrelevant for the case. It even allowed actors to hold both interpretations simultaneously. Some interviewees rejected the premise that the Armenian genocide had legal relevance to the case at hand (understanding this as "political" and outside of the legal realm) while concurrently and formally advocating the truth (or untruth) of the Armenian genocide claim. The following paragraphs illustrate how actors on both sides of the case maneuvered this interpenetration within the formal rules of the game.

In the view of the plaintiffs, the State was quieting a viable perspective in response to political pressure. They had to argue that experts supported their contra-genocide position, because the successful argument of free speech violation relied on the educational worthiness of the documents. Their lawyers referenced academic support for this perspective and expanded the importance of recognition to the Turkish American community. In a request for permission to submit an amicus brief, the TALDF, an arm of the TCA, expressed its concern that its "ability to educate the general public about Turkey and Turkish Americans will be impaired if the District Court stands." The text of the request continues: "Most Turkish Americans espouse a viewpoint upon their ancestral homeland that 
differs in an important respect from that expressed in Ch. 276 of the Massachusetts Sessions laws of 1998. Primarily, they believe that teaching the historical controversy of the Ottoman Armenian tragedy solely within the rubric of the crime of genocide is incorrect and deprives Massachusetts students of crucial context of the devastation inflicted on all civilian populations, Muslims and Christians alike, on the eastern and Caucasus fronts in World War I" (Griswold v. Driscoll, 09-2002 [MA Court of Appeals] [2009], Oct. 15, TALDF Amicus Brief:2).

In its actual amicus brief, the organization refers to the guidelines as "propagandistic" and charges anti-Turkish discrimination. Other amicus briefs for the plaintiffs similarly tie together formal free speech arguments with substantive statements about the genocide. The ACLU, for example, writes in its amicus brief: "As submitted to the legislature, the resources included the website of Georgetown University's Institute for Turkish Studies and other organizations with a viewpoint different from those of other scholars and Armenian groups on whether the treatment of the Armenians constituted genocide" (Griswold v. Driscoll, 1:05-cv12147-MLW [MA District Court] [2009], Nov. 4, ACLU Amicus Brief: 19). Here again, the substantive validity of the Turkish stance becomes a key component of the legal debate.

We see similar interpenetrations between formal and substantive arguments in amicus briefs on the side of the defense. One brief, dated March 8, 2006, submitted by attorney Arnold Rosenfeld on behalf of a community of educators, students, and the Armenian Assembly of America, calls the plaintiffs' assertions "historically and educationally unsupported." The brief includes a lengthy argument as to why the events in the Ottoman Empire constituted genocide, supported by legal and scholarly sources. Having made these arguments, aware of substantive motivations held by some plaintiffs, the majority of the brief addresses the plaintiffs' free speech claims, demonstrating attorney Rosenfeld's mindfulness of the formal issues at stake (Griswold v. Driscoll, 1:05-cv-12147-MLW [MA District Court] [2006], Mar. 8, AAA Amicus Brief).

Similarly, a brief submitted some days later by the Armenian Bar Association and others provides formal arguments on government speech that are interspersed with commemorative considerations. Here the authors argue that governments have the right to commemorate tragedy and to take a non-neutral stance in the case of such violations. Arguments are enriched with analogical bridging to other events addressed by the educational guidelines, including the Holocaust and Ireland's Great Famine. The authors compare attempts to legitimize pro-Turkish materials to legitimizing the Holocaust and other recognized instances of genocide (Griswold v. Driscoll, 09-2002 [MA Court of Appeals] [2009], Oct. 5, Motion to Dismiss, Griswold v. Driscoll, 1:05-cv-12147-MLW [MA District Court] [2006], Mar. 8, Defendants' Reply Memorandum of Law in Support of Their Motion to Dismiss).

An amicus brief from the International Association of Genocide Scholars, filed on April 28, 2006, equally supports the government's formal right to select 
educational material, linking this right with the government's responsibility to train citizens to participate in democracy and to take on national and global responsibilities, resisting indifference. It too, however, simultaneously engages in substantive debate on the appropriateness of the genocide label. It challenges the plaintiffs' position that there are two valid sides to this debate, provides a historical overview of the Armenian genocide, and cites scholarship and widespread international recognition. The authors use the language of genocide denial as the last step in the unfolding of genocide. They engage in extensive analogical bridging to other genocides, referring to the Armenian genocide as the first genocide of the twentieth century, from which Hitler and the Nazis borrowed techniques in orchestrating the Holocaust (Griswold v. Driscoll, 1:05-cv-12147-MLW [MA District Court] [2006], Apr. 28, IAGS Amicus Brief).

In short, Griswold v. Driscoll shows how free speech debates allow substantive arguments to interpenetrate with formal discourse. Two mechanisms are at work. First, formal debate over speech rights invites arguments over the legitimacy of specific speech acts. It partly necessitates such arguments, given that only some speech is free, especially in an educational context. Formal claims are thus contingent on substantive ones. We refer to this phenomenon as the substantive contingency of formal claims mechanism in processes of formal-substantive interpenetration.

Second, legal cases over formal claims open a subterranean realm where coded language allows for substantive debate, hidden behind formal language. Actors may, as in Griswold v. Driscoll, claim to fight for free speech and reject the notion that they pursue a denialist agenda, while simultaneously relying on denialist interpretations of material when articulating their legal argument. Those who stress their sole focus on the formal provide space, simultaneously, for the subterranean insertion of the substantive. Such subtle insertion of substantive concerns into formal debate allows participants to engage in double-speak, with one message openly articulated and the other implied. These actors can reject the charge that a case is about genocide denial, while simultaneously acknowledging as legally relevant "propaganda" or "contra-genocide" sources, categorizations informed by their stance on the Armenian genocide. Subtle changes in language allow these actors to shift back and forth, in what they classify as legally valid lines of argument. Perhaps this is why debates over denial often arise in the context of trials over speech. We call this the subterranean argument device in processes of formalsubstantive interpenetration.

CONCLUSIONS ON GENOCIDE KNOWLEDGE AND TRIALS: LESSONS FROM GRISWOLD V. DRISCOLL

Court cases, even if fought under the guise of formal claims and through formalized procedures, involve substantive claims. Importantly here, they have epistemic consequences. They affect the shape of knowledge and collective memories 
about events under deliberation, including episodes of mass violence. NeoDurkheimians have made this point convincingly, for criminal law generally (Smith 2008) and for human rights trials specifically (Alexander 2004). The present chapter has provided further evidence.

This chapter shows, moreover, that the ritual power of legal proceedings can be a tool in the hands of strategic actors who seek to shape the public understanding of history. Durkheimian and conflict perspectives are not mutually exclusive (Garland 1990). This is in line with insights from past work on the cultural effect of court trials of perpetrators of mass atrocity crimes and their initiation by strategic actors (Hagan 2003; Savelsberg 2015). The Griswold v. Driscoll case illustrates that strategic actors are also active when the subjects of trials are not atrocities themselves, but claims of denial and demands for recognition. While such court cases may be less dramatic than trials of perpetrators of mass atrocity crimes, they may nevertheless shape narratives and affect the epistemic power of competing collectivities.

Past work has also documented how narratives produced and disseminated to the public by legal proceedings reflect not only the cultural power of trials as rituals and the efficacy of strategic actors, but also the institutional logic of law (Pendas 2006; Marrus 2008; Savelsberg and King 2011). The narratives they produce are constrained by the rules of the legal game. This chapter has shown that these constraints also apply to trials in which cultural production is not a byproduct but is the issue at stake. Yet extralegal considerations also play out, often in subterranean ways, in this case debates over the appropriateness of the genocide label for the mass violence committed against the Ottoman Armenians during World War I.

While formally dealing with free speech claims, judges at the district and appellate court levels were intensely exposed to such substantive pronouncements, but they did not use them when deciding, or at least when justifying their decisions. Instead, they stuck to arguments about free speech. Their line of argument thus suggests that they adhered to the rules of the legal game, to use Pierre Bourdieu's language, or to the principles of formal-rational law in Max Weber's terms.

We cannot know whether the judges' decisions were in any way affected by the substantive debate over the appropriateness of the genocide label and the respective sensitivities and interests of the conflicting groups, and whether they thus constituted substantivized law. We do know, however, that parties concerned with free speech issues on the one hand and genocide arguments on the other engaged in strategic coalitions, presenting a discourse in which formal free speech arguments and substantive genocide debates interpenetrated.

The trial also provided a stage on which the parties could carry out their dispute and present their positions to a broad public. It seems as though the victim side won this contest, not just in formal legal but also in substantive terms. The trial, after all, resulted in the mobilization of Armenian Americans, public resonance, and sympathy for their cause, and in an encouragement of other victim groups to 
pursue the public acknowledgment of their history in the education system and in the public sphere (see chapter 9).

Finally, our analysis speaks to the fate of recent legal decision making on issues of free speech in the context of genocide debates. It may challenge common expectations that in cases processed in U.S. courts-in a country that, more than other democracies, privileges individual rights-those sides lose their cases that claim free speech rights, while in several European cases-most famously the Perinçek case before the European Court of Human Rights-free speech arguments have prevailed (Langer 2014). Note, however, that Perinçek was initially found criminally guilty and sentenced in a Swiss court. Note also that a French court had earlier found Princeton historian Bernard Lewis guilty for statements he made in interviews regarding the Armenian genocide (Ternon 1999). Note, finally, an important difference in the character of these European cases compared to the U.S. cases mentioned above, including Griswold v. Driscoll. While the European trials were held against individuals who had made use of free speech rights, even to the detriment of victimized groups (specifically Armenians), American cases such as Griswold v. Driscoll and those involving the University of Minnesota dealt with the right of institutions to practice free speech rights. The decisions in Griswold v. Driscoll additionally stated that the Massachusetts Department of Education had not infringed upon the rights of teachers and students to articulate ideas that were not included in curricular guidelines. The varying nature of plaintiffs and defendants adds complexities that future work should address.

In conclusion, a new type of trial pits those who make free speech claims, some of them seeking to advance denial of genocide, against others who represent, or identify with, victimized groups. While initiators of such trials act with strategic intent, the consequences of resulting court cases are cultural, potentially coloring collective memories and knowledge about the past. Throughout the proceedings in Griswold v. Driscoll, formal legal arguments interpenetrated with substantive concerns with history, memory, and identity, even if only the former became visible in judicial decisions. Substantive concerns intruded through several hidden mechanisms: the decoupling of back stage actors with denialist intent from front stage actors who pursue civil liberties; the substantive contingency of formal claims; and subterranean insertions of substantive claims in formal legal arguments.

This would be the end of the story if we limited ourselves to a classic decisionmaking approach. Yet the decision-making process, be it in the field of politics or that of law, unfolds in a larger cultural environment. Chapter 9 therefore addresses unintended, in fact counterproductive, consequences of denialism in the context of an era characterized by a human rights hegemony. 